\title{
THE DEVELOPMENT OF CONSTRUCTIVE INTERACTION SKILL AS A COMPONENT OF SOCIAL SUCCESS OF JUNIOR PUPIL
}

\author{
Alexander Mytnyk \\ National Pedagogical Dragomanov University, Ukraine \\ Olena Matvienko \\ National Pedagogical Dragomanov University, Ukraine \\ Andrii Guraliuk \\ V.O. Sukhomlynskyi State Scientific and Pedagogical Library of Ukraine, Ukraine \\ Nataliia Mykhalchuk \\ Rivne State University of Humanities, Ukraine \\ Ernest Ivashkevych \\ Rivne State University of Humanities, Ukraine
}

\begin{abstract}
The article proves that in order to achieve success in a person's society, it is important to be not only intellectually developed, but also to be able to work effectively in a team. The analysis of a scientific literature shows that there is a lack of research aimed at the purposeful development of students' ability to interact constructively with others. The purpose of the article is to reveal the theoretical and practical foundations for the development of the ability to constructively interact with others in primary school students. The following methods were used: theoretical analysis of a scientific literature on the problem of research, modeling, in order to describe the technique of constructing tasks for joint activities; empirical methods: diagnostic techniques, psychological and pedagogical experiment; methodology for building teaching as a holistic creative process.

The article describes the essence of constructive interaction between the subjects of the educational process, presents the psychological and pedagogical conditions for the development of students of primary school age, the ability to constructively interact with others, namely: the introduction of the course "Logic" in the educational process of primary school in grades from 2 to 4, tasks, related to the content of the course "Logic", in the lessons on the disciplines of the humanities and natural-mathematical cycles; the use of interactive teaching methods in the educational process; creation and implementation of tasks for joint educational activities, providing for the "I - inclusion" of everyone in joint work. A system of tasks related to the content of the course "Logic" is presented, examples of tasks of a combined nature are given and the process of working on them is described. The creation of tasks for joint educational activities in large and small groups by means of ICT is described, examples of such tasks are given, the process of working on such tasks is described.

With the help of the introduction of certain diagnostic techniques and the organization of experimental research at the all-Ukrainian level, the positive dynamics of the development of
\end{abstract}


Mytnyk et al., 2021. The Developmento of Constructive Interaction Skill as a Component of Social Success of Junior Pupil

students' ability to interact constructively with others and, as a consequence, the effectiveness of the named psychological and pedagogical conditions for the development of the presented skill have been proved.

Keywords: constructive interaction of individuals of educational process, joint educational activity, interactive method of training, logical knowledge, logical skills, ontos.xyz service, social success of the younger schoolchildren, teaching methods.

\section{Introduction}

Changes in the modern world are brought about by the globalization of economic and socio-political processes that have led to a shift in the XXI century of educational paradigm. Based on the inseparable link between the quality of education and the quality of life in society, it is possible to consider education as one of the means expanding children and adults`opportunities as active reorganizers of their societies. Training covers all the values that enable people to learn to "live together" in the world characterized by pluralism and diversity.

For an individual to achieve social success, it is important to be not only intellectually developed, which is manifested in the ability to obtain and process information understanding what is critically important and what's merely a "detail"; be proactive in planning steps to be taken; to infer cause-and-effect relationships; to draw reasonable conclusions and, as a result, to prove his or hers point and the value of what has been created to professional community clearly, consistently and in a well-argued manner. In addition, we need to be able to work effectively in a team. We believe that this skill is mastered due to dialogic links in the thinking structure, namely: "thinking for oneself" (presentation of a certain idea), "thinking for another person" (the ability to put oneself in another person`s position and see a situation through their eyes) and "thinking together with another person "(taking the position of "we" on constructing a single draft decision).

Working together, it is important to respect the opinion of others, control one`s temper and understand the emotions of others - it will help to adhere to moral standards and rules in the interaction process. Based on the above, it is necessary, starting from the first grade, to develop schoolchildren's constructive interaction skills. These skills will help growing individuals to transform themselves and others for the better, to analyze and evaluate the consequences of these changes as well as to prove the value of what is created to other people. Thus, constructive interaction skills as an elementary schoolchild`s integral quality are the main component of social success.

The aim and objectives of the article are to provide insight into the theoretical and practical foundations underlying the development of constructive interaction skills in elementary schoolchildren, namely: to define the concept of 
constructive interaction among the subjects of the educational process; to outline the psychological and pedagogical conditions for the development of elementary schoolchildren`s constructive interaction skills; to describe the all-Ukrainian experimental study on this skill development.

The article employs the following research methods and techniques: theoretical analysis of the scientific literature on the research subject; modeling to describe the technique for cooperation task composition; empirical methods: diagnostic methods, psychological and pedagogical experiment; methods of learning design as a holistic creative process.

\section{Literature Analysis}

So many scientists associate the organization of interaction in learning with the development of such moral qualities as respect for the opinion of others, sympathy and tolerance. Philosopher W.James believes that the quality of interaction is influenced by its participants temperament. The scientists note that it "has an influence similar to facts or principles affecting the choice of a softer or tougher view of life" (James, 1995, 8). We support G.Kostiuk`s position claiming that in the learning process, the intellect should become verbal, and speech should be intellectualized, i.e. be clear, brief and argumentative (Kostiuk, 1969). In our opinion, the ability of interaction participants to prove their points significantly affects interaction constructiveness. A. Savenkov's research reveals the mission of social intelligence in constructive interaction with others. The scientist noted that the presence of social intelligence helps to understand the motives of another person's behavior, to predict their behavioral reactions in certain situations underlying success in social adaptation and integration (Savenkov, 2018). In our opinion, the main social intelligence criterion is the ability to put oneself in another person`s position and see a situation through their eyes and, as a consequence, either accept another person`s viewpoint or tactfully disagree by proving the proposed opinion to be wrong. For success in communication in general and, in particular, in constructive interaction with others, it is important to understand and be able to control one`s temper, which serves as a criterion indicating the presence of emotional intelligence. This means that emotional intelligence is a component of social intelligence. According to Peter Salovey and John Mayer, emotional intelligence is the ability to perceive and understand the manifestations of personality expressed in emotions as well as to control emotions based on intellectual processes. In other words, emotional intelligence, in their opinion, is comprised of the following 4 parts: 1) the ability to perceive or feel emotions (both one`s own and other people`s ones); 2) the ability to use 
Mytnyk et al., 2021. The Developmento of Constructive Interaction Skill as a Component of Social Success of Junior Pupil

emotions to support rational thinking; 3) the ability to understand what is expressed by an emotion; 4) the ability to control emotions (Mayer \& Salovey, 2005).

Based on the above, we may conclude that the intentional development of schoolchildren's constructive interaction skills in the educational process will help a teacher to develop in them a personalized way of talking, that is, not only the expression of objective ideas but also their attitude to what is said as well as certain emotional and volitional qualities.

\section{Theoretical and Applied Bases of Research}

The XXI century is characterized by the deepening and acceleration of comprehensive socio-economic, socio-cultural, and political processes determining the development of mankind at the present stage. In these conditions, as emphasized in the conception of the New Ukrainian School (Kabinet Ministriv Ukrayiny, 2016), the role of education as a social institution, where the formation and development of each individual takes place, is the most responsible and important.

Among the education development trends of the XXI century, we should emphasize the main ones affecting elementary schoolchildren`s social success (Matviienko, Tutova, 2019), namely:

The first trend is humanization, which is based on the recognition of man as the highest social value. The trend requires the creation of a new type of education with the priority of training focused on the personality of "Z" and "Google" generation students; orientation towards the development of their strengths and capabilities; meeting their various educational needs, and cultivating a sense of self-worth, tolerance, empathy and independence;

The second trend is education humanitarisation aimed at forming personal and corporate culture, "multidimensional" thinking, digital literacy, "smart" tolerance and a holistic view of the world.

The third trend is the national orientation of education consisting in the inseparability of education from national and patriotic orientations, the preservation and enrichment of the Ukrainians, other nationalities and nations national values as well as the formation of cultural pluralism and respect for cultural diversity;

The fourth trend is educators' competence in working in the modern educational environment, their ability to organize successful cooperation, create comfortable conditions for subject-subject relations and cooperation effectively building partnership with different students in the classroom in such a way.

The transition from authoritarian and directive pedagogy to personalityoriented teaching and education largely depends on the development of subject- 
subject relations between a teacher and students in the educational environment, their interpersonal interaction on the basis of a dialogue, cooperation and partnership. The problem of relations between the subjects of the educational process has always been relevant. Its solution directly affects the efficiency of the introduction of new educational technologies in student teaching as well as the level of the individual`s spiritual growth (Matvienko, 2009).

Interaction consists of actions. Each action is a system that contains the following complex formations: an active individual, objects of action or an individual who the action is directed at; action means or instruments; an action method or a method of using means, the affected individual's reaction or the action result.

Each of the subsystems is characterized by certain mechanisms for constructive interaction development:

- relationships (a teacher and a student as the subjects of interaction are capable of self-organization and self-realization, and therefore, influencing each other they change qualitatively);

- $\quad$ connections (they characterize the nature of changes, the activity level of each pedagogical interaction subject);

- pedagogical influence (involves teachers`active actions; seeking to achieve their goals in the learning process, they use encouragement, persuasion, the creation of a situation of success and other methods);

- mutual understanding (contributes to the formation of a single conceptual field for interaction subjects);

- coordination (this mechanism of interaction is associated with the search for tools that ensure action coordination and consistency in operations);

- cooperation (interaction subjects participate in the preparation of joint projects or different but related tasks) (Matviienko, 2009).

Thus, we consider constructive interaction as a process aimed at development and self-development penetrating the "core" of personal relationships in all activities.

In the humanitarian sphere, the use of constructive interaction as a basis, a method of cognition of processes taking place all-around, leads to the traditional interpretation of human interaction but only through their influence on each other. At the same time, understanding interaction as an interrelation process between subject and objects implies not only directed activity but also a focused influence and coexistence of subjects and objects (Matviienko, 2016).

To organize favorable conditions aimed at developing constructive interaction skills in elementary schoolchildren, a modern teacher should be prepared to ensure constructive interaction in the elementary school educational 
Mytnyk et al., 2021. The Developmento of Constructive Interaction Skill as a Component of Social Success of Junior Pupil

environment.

Thus, constructive interaction between a teacher and students should be at the core of the educational process in elementary school. The specificity of constructive interaction in "teacher-students in the classroom" and "teacherstudent" subsystems lies in the fact that a teacher`s main focus is not on the result of certain knowledge acquisition but on the process of its mastering. The content of scientific concepts in constructive interaction with a teacher does not takes hold in each student `s mind - rather, it is consistent with the content that a student is able to read into it at the time of learning. Its subjective content may or may not be the same, but it is always in a teacher`s focus. In this sense, learning becomes a holistic creative process, where creativity is the formation by schoolchildren of their personal opinion or position and then - the emergence of author's creative products, a variety of them. Psychological comfort in the process of interaction with a teacher removes students' fear of making a mistake significantly improving their self-believe, it creates a basis for free selfexpression: children forget about being afraid to express their thoughts, make mistakes, become unreserved in manner and, as a result, they are willing to think.

Let us consider the psychological and pedagogical conditions, the presence of which contributes to the development of the investigated skills in students:

1. The introduction of the "Logic" course in the elementary school educational process in grades $2-4$. First and foremost, taking this course will help to develop in the younger generation all the mental operations and qualities of thinking, as well as the ability to express their thoughts clearly and convincingly; ability to think beyond the specific content and focus on the structure of their opinion; ability to independently obtain new information; create their own products (new tasks in logic, mathematics and other disciplines); ability to think and plan their steps proactively. The ability to think is related to the ability to identify a problem and be aware of it; the ability to apply previously learned (known) ways to solve the problem in a new educational or life situation (extrapolation, selection and analysis of facts, finding connections of the new with what was previously learned, etc.); make assumptions about solving the problem; substantiate and prove the assumptions.

The information support for the "Logic" course in grades 2 - 4 is a syllabus and textbooks - for each grade their own ones (Mytnyk, 2007; Mytnyk, 2008; Mytnyk, 2009).

2. The introduction of tasks according to the "Logic" course syllabus in the lessons on the disciplines of the humanities, natural and mathematical sciences. The tasks are as follows:

The first block. To find specific concepts according to the given generic notion or vice versa; to find among the given concepts an odd one out and to 
give reasons for such an opinion.

The second block. To give a definition of the concept or to find a mistake in the proposed definition.

The third block. To construct a "chain" narrowing down or broadening the concept meaning. In the narrowing "chain", each subsequent concept must be narrower in scope than the previous one. In the "chain" of generalization, each subsequent concept has to be broader in meaning than the previous one.

The fourth block. To express relationships between the scope of these concepts using Euler circles.

The fifth block. To determine the truth of the given simple or complex assertion.

The sixth block. To make a simple assertion using the given concepts or according to a picture, starting with a certain generic word: all (each, any), some (at least one), none, always, sometimes, never.

Some blocks can be combined into one task. For example, in a math lesson in the process of generalization and systematization of what has been learned during the elementary school course, children can be offered the following task: "To express the relationships between the scope of concepts using Euler circles.
A - natural numbers
$\mathrm{B}$ - even natural numbers
C - odd natural numbers
D - four-digit numbers
E - five-digit number
$\mathrm{F}$ - numbers in the tens of thousands 'place consisting of 3 digits

Then we can ask students to make simple true assertions starting each of them with a certain generic word ("all", "some", "none") using these concepts. The students explore that when making assertions with the word "all" they use concepts the scope of which include each other; with the word "some" the scope of used concepts intersect; with the word "none" the scope of concepts is independent. There are many such assertions. For example, "all even natural numbers are natural numbers", "some five-digit numbers are numbers in the tens of thousands` place consisting of 3 digits", "no even natural number is an odd natural number".

3. The use of interactive teaching methods in the educational process. As interactive we consider methods, the use of which facilitates the simultaneous development of both hemispheres of the child's brain. The introduction of interactive teaching methods in lessons will help a teacher to enrich the educational process with the elements of research, search, the comparison of various facts, phenomena, positions, and conclusions. Thus, at the level of gaining new knowledge, the following methods can be used: problem- based 
Mytnyk et al., 2021. The Developmento of Constructive Interaction Skill as a Component of Social Success of Junior Pupil

search dialogue (propels the development of mainly the left hemisphere of the brain) in combination with the method of figurative perception (promotes the development of predominately the right hemisphere of the brain). At the level of the formation of intellectual and creative skills the following methods can be of use: brainstorming, a problem- based search dialogue, the methods of inversion, empathy and incident, a didactic game and synectics (Mytnyk, 2006).

4. The creation of collaborative learning activity tasks that imply the use of ICT, providing "I - involvement" of everyone in collaborative work. Working on these tasks will help a teacher to activate students`creative thinking, develop its flexibility, dialogic links in the intelligence structure as well as emotional and volitional qualities.

The general task performance algorithm is as follows: each member of the group works on a subtask. Then, in collaboration, students combine subtask solutions into a single whole forming a new product. The use of ICT tools helps to involve all students in collaborative activities.

To date, a large number of free online resources have been created to support the educational process, some of which are quite easy to use in elementary school. One of them, for example, is LearningApps.org (2021) - a Web 2.0 application to support the learning and the teaching process through interactive modules.

LearningApps.org (2021) service is designed to develop interactive tasks that can be used working individually and in groups. To create an author's resource at a high quality level, it is required to have minimal ICT skills. Today, hundreds of exercises for elementary school are publicly available.

Here are some examples of exercises that can be used for group work. In order for each and every student to participate in group work, each student should get their own task, albeit typical, the result of which has to be significant for the whole group and there has to be no opportunity to copy it from classmates.

Let us consider an exercise for a nature study lesson on wildlife on our planet, which can be delivered in the 4th grade while studying the topic: "The nature of continents and oceans." Students are divided into groups according to the number of continents (the figure does not show Antarctica). The students are asked to choose animals that can be found on "their" continent. The winners are the group that has "inhabited" it's part of the map with more "correct" inhabitants and fewer animals living on other continents. Fig. 1.a. illustrates the task for one of such groups. 


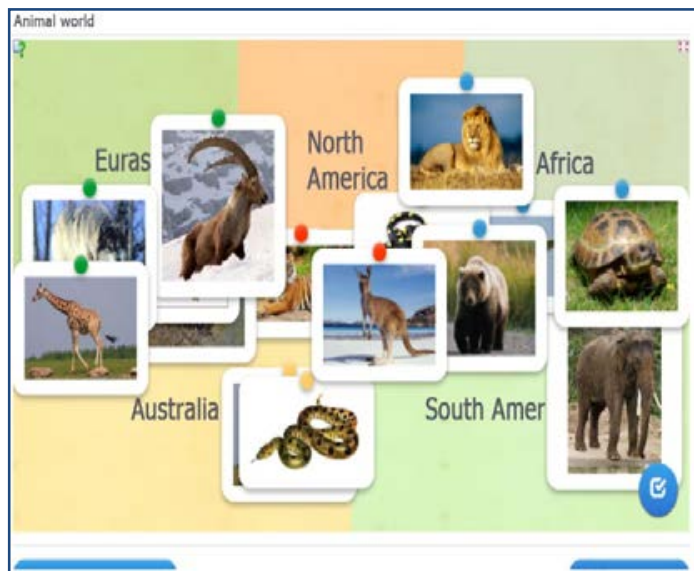

a)

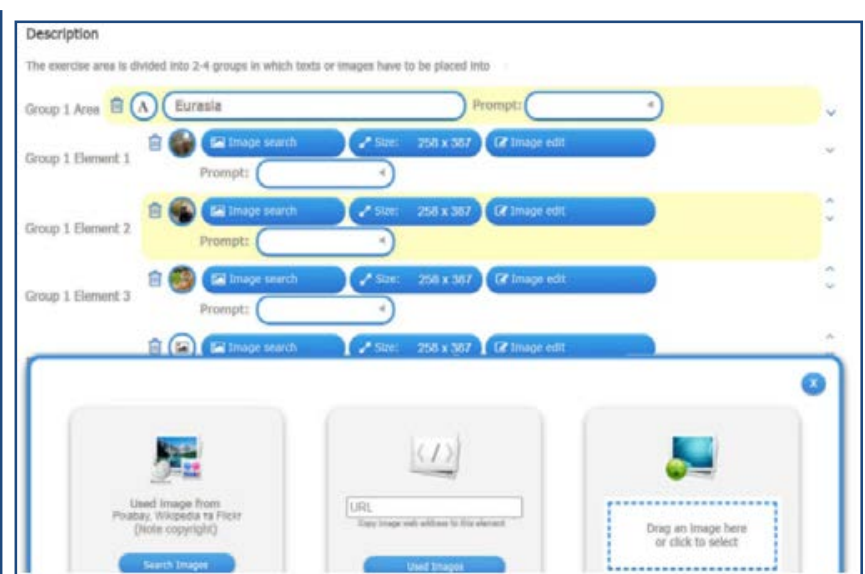

b)

Figure 1 Wildlife in Different Parts of the World

Then each group makes up a story about wildlife on "their" continent. The members of the groups ask each other questions and learn the names of the continents.

The development of training exercises using the LearningApps.org service is so simple that they can be developed by students (Fig. 1b). To organize this type of activity, a teacher needs to choose an exercise type (preferably a readymade exercise and use the option "create a similar task"). Choose a topic and establish conditions.

To make it easier for teachers to organize cooperative learning activities, we have developed the service Ontos.xyz (2021) designed to create the new integrations of existing electronic resources (Guraliuk et al., 2020). The built-in tools of this service make it possible to easily build a task structure both in the form of an ontograph (Fig. 2.a), where each node contains some information and in the "usual" form of an electronic textbook (Fig. 2.b.)

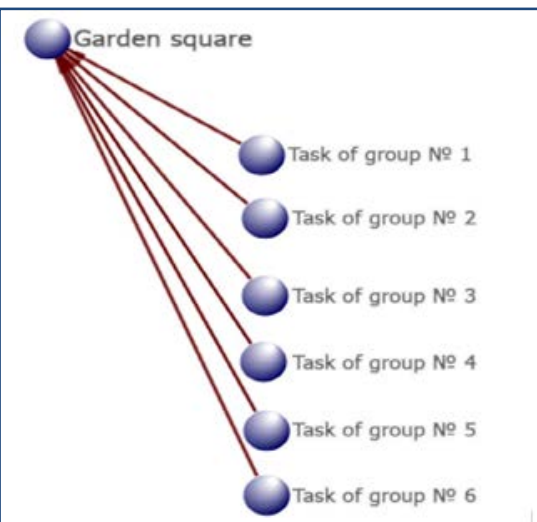

a)

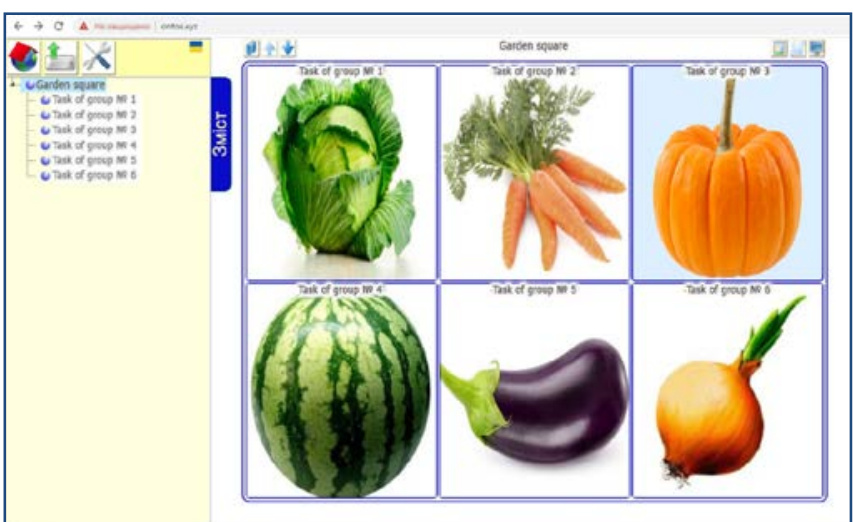

b)

Figure 2 Interface of an Ontos.xyz Service Interactive Textbook 
Mytnyk et al., 2021. The Developmento of Constructive Interaction Skill as a Component of Social Success of Junior Pupil

When selecting a textbook page, its content appears with a task and the means of its solution (Fig. 3). Text, graphics, audio and video files, documents in pdf, doc, docx and xls formats, presentations, web 2.0 applications, etc. can be used to fill the page.

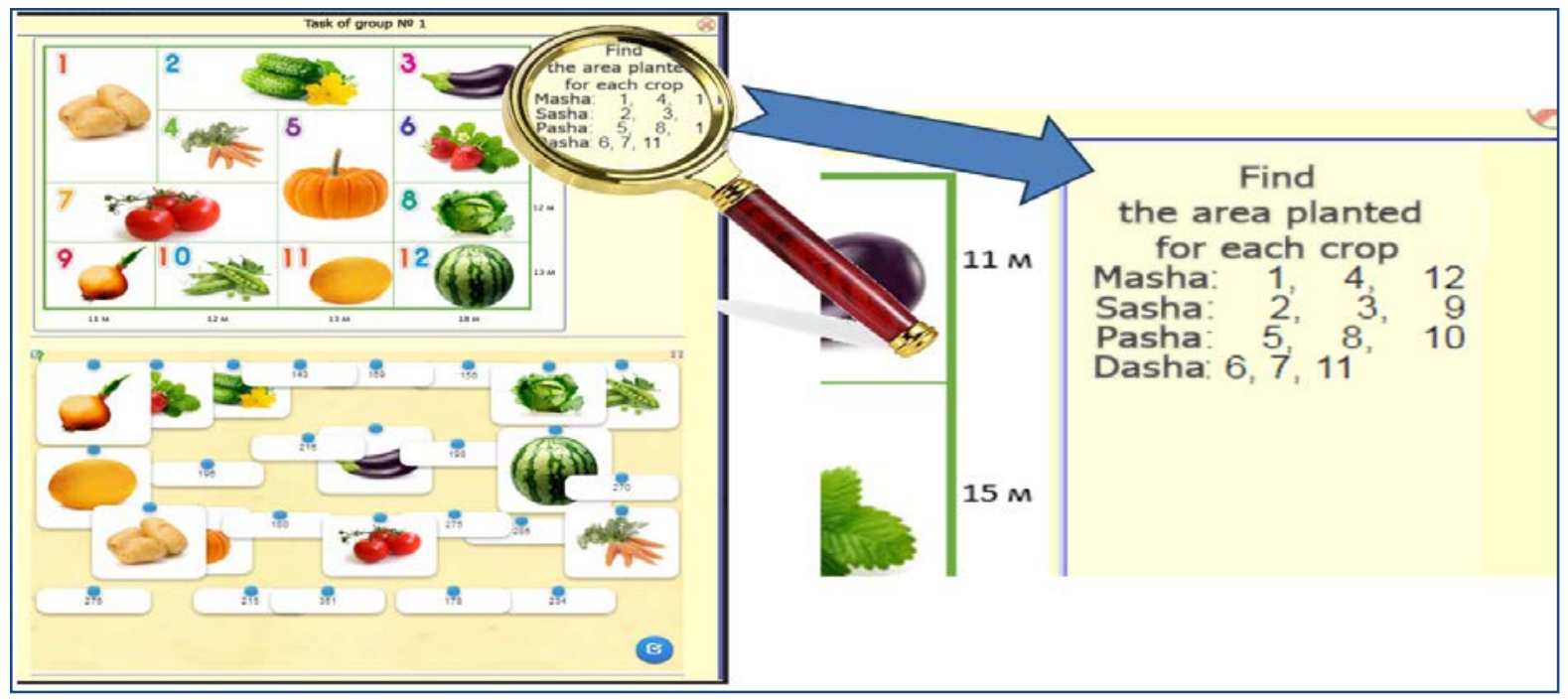

Figure 3 Example of Using the LearningApps.org Service Application as the Ontograph Node Content (electronic textbook page content)

Thus, applications created using the LearningApps.org service can be included in interactive textbooks. In a math lesson in the fourth grade studying the topic "The area of a rectangle and a square", students can be offered a task illustrated in Fig. 3. In Fig.3, the task is a picture that shows the size of the rectangular areas and the text directly specifying what plot area each student needs to determine. At the bottom of the page, there is an interactive game where students have to combine images of a crop growing in a plot with a number equal to the plot area (there are three times as many numbers on the screen as the plots).

Then the new task is formulated as follows: three crops were sown in a large field: sunflower, corn and wheat. It is known that the area of the field where the sunflower was sown is such as the sum of the areas of the smallest plots; the area of the field in which the corn was sown is such as the sum of the areas of the middle plots; the sum of the areas of the largest plots corresponds to the area where the wheat was sown. In each group, during the discussion, the smallest plots and their sum are found, and similar calculations are performed with the medium and largest ones.

The next step is intergroup work (work in large groups) The representatives of each small group add together the values of the areas of the smallest plots, similar work is carried out on calculating the sums of the areas of the middle and 
largest plots. Finally, the students calculate the area of the whole field where the sunflower, the corn and the wheat were sown, i.e. the sum of the areas occupied by these crops. The work described above involves all students, where each of them performs both an individual and group task together with others.

Thus, the use of modern information technology can help teachers make the educational process joyful, exciting and emotionally rich (Guraliuk et al., 2018).

In elementary school reading lessons, we recommend organizing work in a large group. In this case, all students are a group working on the same problem. For example, "Is it right to say that a fairy tale teaches how to live in the world?", "What is happiness?" etc. A teacher prepares students for such a lesson in advance, offers to familiarize themselves with certain literary works suggesting a solution to the given problem. During the lesson, first the discussion of the outlined problem is carried out in "small" groups (4 - 6 students in each), then each "small" group presents the results of the discussion to the teacher and classmates. Children substantiate their ideas using excerpts from certain literary works (selective reading). Finally, within the "large" group, the results of the search for a solution to the problem carried out in "small" groups, are discussed to identify the only correct solution or an original, a rational one, etc. At the end of the lesson, students can make up a single story or an argumentative essay on the problem outlined at the beginning.

In this case, it is advisable to use the method of the incident, namely: in a chain order (one by one) students create a story, making up one sentence within a time limit- each student has one minute.

\section{Research Results}

The presented psychological and pedagogical conditions were introduced into the educational process in terms of the all-Ukrainian experimental study on the didactic and methodological system of children's creativity development in preschool and general education institutions in 2012 - 2017. The experimental study took place in such Ukrainian cities as Kyiv, Mykolayiv, Ivano-Frankivsk, Ternopil.

The study involved 683 experimental grade students. Constructive interaction skills are based on cognitive interest, the desire for continuous selfdevelopment, developed conceptual and divergent thinking as well as intellectualized speech. Based on the above, we used the following diagnostic techniques: "What I like at school" (Luskanova, 1993), the Alternate Uses Task (Guilford, 1967) and the Inkblot Test (Rorschach, 1921) with the fourth-graders at the ascertaining stage (2012) and the control stage (2016) of the experiment 
Mytnyk et al., 2021. The Developmento of Constructive Interaction Skill as a Component of Social Success of Junior Pupil

The results of the "What I like at school" projective method application showed that at the ascertaining stage in most experimental grade students, external motivation for learning and neutral attitude dominated (67\% - 457 students) while at the control stage, cognitive motivation and pragmatic attitude became dominant (78\% -533 students). The interpretation of the results is given in Table 1.

Table 1 Interpretation of the Results of the "What I like at school" Projective Methodology

\begin{tabular}{|c|c|}
\hline at the ascertaining stage & at the control stage \\
\hline $\begin{array}{l}\text { Most of the pictures illustrated such learning } \\
\text { situations, where a teacher was working only } \\
\text { with one student at the blackboard as well as } \\
\text { various game situations: children playing in } \\
\text { the school corridor during a break; they } \\
\text { portrayed themselves as performing in the } \\
\text { school assembly hall on the stage or simply } \\
\text { pictured the assembly hall with festive } \\
\text { attributes. The children in such pictures had } \\
\text { cheerful facial expressions. }\end{array}$ & $\begin{array}{l}\text { The pictures mostly illustrated different } \\
\text { learning situations related to such subjects as } \\
\text { Math, Logic, Ukrainian Language and Art } \\
\text { Work; in the pictures, there were depicted } \\
\text { children in the classroom (at the blackboard } \\
\text { or sitting at their desks in groups) and a } \\
\text { teacher; the pictures could be characterized } \\
\text { by bright colors and the children and } \\
\text { teachers cheerful facial expressions. }\end{array}$ \\
\hline
\end{tabular}

The analysis of the Alternate Uses Task application results (Guilford, 1967) revealed that while at the ascertaining stage most students showed fluency only in the alternative uses of objects - the same type of proposals (62\%: - 423 students), at the control stage, most elementary school graduates were characterized by high divergent productivity - the students showed fluency, flexibility and originality in the ways of using the proposed objects $(81 \%-553$ students).

The analysis of the results of the Rorschach test application (the Inkblot Test) showed that describing how the inkblot looked like, the children at the ascertaining stage produced mostly one-word statements (59\% - 402 students); at the control stage, they used everyday images or artistic descriptive associations (for example, "a black cloud is floating among the white ones", "the enemy force has surrounded the Cossacks", "old Shapoklyak`s rat", etc.) - 77\%: or 525 students.

Logic knowledge and skills that students mastered in the corresponding lessons helped in giving arguments in favour of their own opinion, the analysis and assessment of the validity of their own and others' opinions as well as in the process of formulating and making informed decisions during educational discussions in the disciplines of the humanities and, natural and mathematical sciences.

The development level of the studied skills was assessed by calculating the 
arithmetic mean of the results obtained in relation to the above methods. We illustrated the dynamics of the development of the students' constructive interaction skills on the pie charts (Fig. 1).

\section{Ascertaining stage}

Experimental group

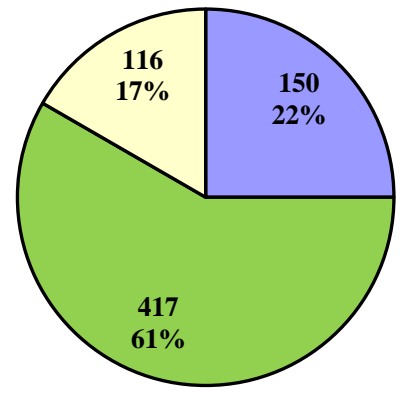

\section{Control stage}

Experimental group

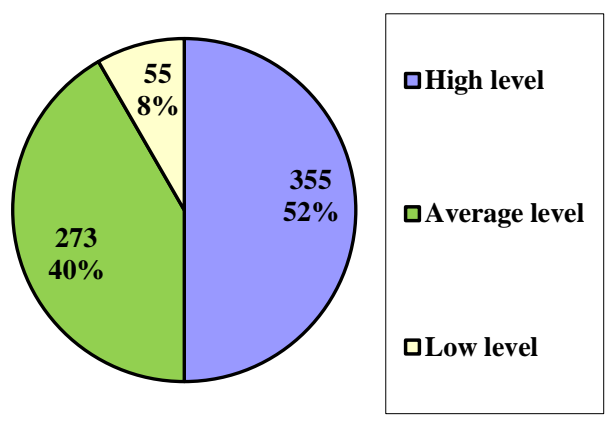

Figure 4 Dynamics of the Development of the Students' Constructive Interaction Skills

The positive dynamics of the described results indicated that the proposed psychological and pedagogical conditions for the development of elementary school students' constructive interaction skills were proved to be effective. The experimental research revealed that most students were characterized by predominantly cognitive motivation, developed divergent thinking and intellectualized speech which was clear, brief and argumentative

Constructive interaction skills were manifested by all the experimental grade students, namely: tolerance towards other, even completely opposite, points of view and means (ways) of solving creative tasks and, at the same time, the ability to hold their ground; ability to provide a factual basis for their views; ability to work in a team and, more specifically, to contrast personal statements (opinions and positions) with other students and teachers statements, their analysis, synthesis in order to develop a correct (constructive and rational) teamwork strategy.

\section{Conclusions}

The introduction of the described conditions into the educational process will help a teacher to make each student an active participant in the educational process. In such conditions, students have a desire to get their voice heard, to express their own opinion on the topic they are studying, to offer their options for solving the problem, because they feel that their position is valuable to a teacher. This means that children have a desire to think, which is a factor 
Mytnyk et al., 2021. The Developmento of Constructive Interaction Skill as a Component of Social Success of Junior Pupil

contributing to the formation of constructive interaction skills.

Further research will be aimed at creating psychological and pedagogical support for the formation of a socially successful personality of students studying in general secondary education institutions. The present study started in September 2018 is a continuation of the previous one and is carried out within the framework of the all-Ukrainian experiment and will last until June 2023 (order of the Ministry of Education and Science of Ukraine $N$ №887 of 08.08.2018)

\section{References}

Guilford, J.P. (1967). The nature of human intelligence. McGraw-Hill.

Guraliuk, A.G., Mytnyk, O.Ya., Sydorkin, Ye.M. (2018). Rozvytok kohnityvnoyi kompetentnosti uchniv u navchal"no-vyxovnomu procesi ZNZ zasobamy informacijnokompyuternyx texnolohij. Mizhdyscyplinarni doslidzhennya skladnyx system, №13, S. 71-82.

Guraliuk, A.G., Rostoka, M.L., Cherevychnyi, G.S., Zakatnov, D.O., Pavlysh, T.H. (2020). Dual-Component Ontograph Visualization. IOP Conference Series: Materials Science and Engineering, Volume 1031, International Conference on Technics, Technologies and Education 2020 (ICTTE 2020) 4th-6th November 2020, Yambol, Bulgaria. Retrieved from https://iopscience.iop.org/article/10.1088/1757-899X/1031/1/012119/ meta\#artAbst

James, W. (1995). Pragmatism. translated from English by P. Yushkevych. Kyiv: Ukraine. $284 \mathrm{p}$.

Kabinet Ministriv Ukrayiny. (2016). Rozporyadzhennya «Pro sxvalennya Koncepciyi realizaciyi derzhavnoyi polityky u sferi reformuvannya zahal"noyi seredn"oyi osvity “Nova ukrayins"ka shkola” na period do 2029 roku». vid 14 hrudnya 2016 r. № 988-r. Uryadovyj kur'yer vid 28.12.2016 № 246.

Kostiuk, H.S. (1969). Navchal"no-vyxovnyj proces i rozvytok osobystosti. Kyyiv: Radyans"ka shkola,. $608 \mathrm{~s}$.

LearningApps.org. (2021). LearningApps.org is a Web 2.0 application, to support learning and teaching processes with small interactive modules. Retrieved from http://learningapps.org/about.php

Luskanova, N.G. (1993). Metody issledovanija detej s trudnostjami obuchenija. Metodicheskie rekomendacii. — M.: Folium, 1993. —- 64 s.

Matvienko, O.V. (2009). Pidhotovka majbutnix uchyteliv do pedahohichnoyi vzayemodiyi: monohrafiya. Kyyiv: NPU im. M. P. Drahomanova, 384 s.

Matviienko, O.V. (2016). Theoretical bases of teacher's professional formation: Edizioni M. Economics, management, law: socio-economical aspects of development: Collection of scientific articles, Volume 2. Psychology. Pedagogy and Education. Roma, P. 237-239

Matviienko, O., Tutova, T. (2019). Criteria, Indicators and Levels Future Primary School Teacher's Readiness to Collaboration with Heterogeneous Groups of Students: Intellectual Archive, Volume 8, No. 2 (April- June). Toronto: Shiny Word Corp., Canada. P. 190-201.

Mayer, J.D., Salovey, P. (2005). Emotional intelligence. Retrieved from: https://cdn2.psychologytoday.com/assets/attachments/1575/rp2008- 

mayersaloveycarusob.pdf

Mytnyk, O.Ya.(2006). Yak navchyty dytynu mystectva myslennya. K.: Pochatkova shkola. $104 \mathrm{~s}$.

Mytnyk, O.Ya. (2007). Lohika. 2 klas. Eksperymental"nyj navchal"nyj posibnyk. 2-he vyd. K.: Pochatkova shkola. $104 \mathrm{~s}$.

Mytnyk, O.Ya. (2008). Lohika. 3 klas. Eksperymental"nyj navchal"nyj posibnyk. 2-he vyd. K.: Pochatkova shkola. $104 \mathrm{~s}$.

Mytnyk, O.Ya. (2009). Lohika. 4 klas. Navchal"nyj posibnyk. 2-he vyd. dop. i pererobl. K.: Pochatkova shkola. $80 \mathrm{~s}$.

Ontos.xyz. (2021). Service for creating and displaying data ontologies. Retrieved from http://Ontos.xyz

Rorschach, H. (1921). Psychodiagnostik Talfen. Huber, Bern.

Savenkov, A.I. (2018). Struktura social'nogo intellekta Sovremennaja zarubezhnaja psihologija. 2018. Tom 7. \# 2. S. 7-15. doi:10.17759/jmfp.2018070201 